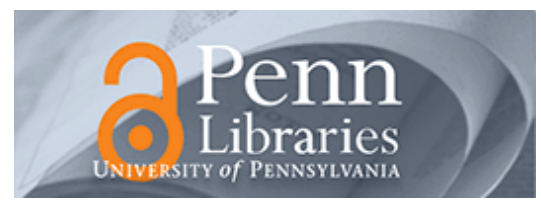

University of Pennsylvania

ScholarlyCommons

PSC Working Paper Series

5-10-2007

\title{
Divorce-Law Changes, Household Bargaining, and Married Women's Labor Supply Revisited
}

Betsey Stevenson

University of Pennsylvania, betsey.stevenson@wharton.upenn.edu

Follow this and additional works at: https://repository.upenn.edu/psc_working_papers

Part of the Demography, Population, and Ecology Commons

Stevenson, Betsey, "Divorce-Law Changes, Household Bargaining, and Married Women's Labor Supply Revisited" (2007). PSC Working Paper Series. 7.

https://repository.upenn.edu/psc_working_papers/7

Stevenson, Betsey. 2007. "Divorce-Law Changes, Household Bargaining, and Married Women's Labor Supply Revisited." PSC Working Paper Series PSC 07-03.

This paper is posted at ScholarlyCommons. https://repository.upenn.edu/psc_working_papers/7

For more information, please contact repository@pobox.upenn.edu. 


\title{
Divorce-Law Changes, Household Bargaining, and Married Women's Labor Supply Revisited
}

\begin{abstract}
Divorce law changes made in the 1970s affected marital formation, dissolution, and bargaining within marriage. By altering the terms of the marital contract these legal changes impacted the incentives for women to enter and remain in the labor force. Whereas earlier work had suggested that the impact of unilateral divorce on female employment depended critically on laws governing property division, I show that these results are not robust to alternative specifications and controls. I find instead that unilateral divorce led to an increase in both married and unmarried female labor force participation, regardless of the underlying property laws.
\end{abstract}

\section{Keywords}

AFDC, Aid to Families with Dependent Children, Assets, Bargaining power, Bargaining within marriage, Compensation, Cooperative bargaining models, Current Population Survey, Division of property, Divorce, Divorce law, Divorce reform, Employment, Female employment, Female labor force participation, Household allocation, Household decision making, Labor force, Labor supply, Laws, Marital aspirations, Marital behavior, Marital contract, Marital dissolution, Marital expectations, Marital formation, Marital partners, Marital property, Marriage, Property division, Property division laws, Property laws, Settlements, Statistics, Survey Data, Unilateral divorce

\section{Disciplines}

Demography, Population, and Ecology | Social and Behavioral Sciences | Sociology

\section{Comments}

Stevenson, Betsey. 2007. "Divorce-Law Changes, Household Bargaining, and Married Women's Labor Supply Revisited." PSC Working Paper Series PSC 07-03. 


\title{
Divorce-Law Changes, Household Bargaining, and Married Women's Labor Supply Revisited
}

\author{
Betsey Stevenson \\ Business and Public Policy Department \\ The Wharton School \\ University of Pennsylvania \\ 1454 Steinberg Hall-Dietrich Hall \\ Philadelphia, PA 19104-6372 \\ tel 215 898-3019 \\ fax $215898-7635$ \\ betsey.stevenson@wharton.upenn.edu \\ http://bpp.wharton.upenn.edu/betseys/index.asp
}

\begin{abstract}
Divorce law changes made in the 1970s affected marital formation, dissolution, and bargaining within marriage. By altering the terms of the marital contract these legal changes impacted the incentives for women to enter and remain in the labor force. Whereas earlier work had suggested that the impact of unilateral divorce on female employment depended critically on laws governing property division, I show that these results are not robust to alternative specifications and controls. I find instead that unilateral divorce led to an increase in both married and unmarried female labor force participation, regardless of the underlying property laws.

JEL Codes: D1, J1, J2, K36, N3

Keywords: Marriage, divorce, household allocation, female labor force participation

This project has drawn on the advice of many generous friends and colleagues, including Brigitte Madrian, Robert Pollak, and Justin Wolfers. Special thanks to Adam Isen for excellent research assistance and Jeff Gray for sharing his programs. Generous funding from the Zull/Lurie Real Estate Center is gratefully acknowledged.
\end{abstract}


In the late 1960s and 1970s the laws governing both the grounds for divorce and rules for dividing marital property upon divorce were significantly altered. Since then scholars have examined the effects these new laws had on family dissolution, formation, and behavior within marriage. Early work appealed to the Coase theorem, arguing that changing who has the right to divorce — the person desiring a divorce or the spouse preferring to remain married—would have no effect on the actual divorce rate. Empirical work using both cross-section and panel data supported this hypothesis, finding little effect of the legal change from mutual consent to unilateral divorce on the divorce rate. ${ }^{1}$

The finding of no effect of divorce laws on the divorce rate led Gray (1998) to argue that unilateral divorce should only effect female labor supply to the extent that it changes bargaining within households. Thus, reforms to divorce laws provided a unique opportunity to empirically test competing models of the household bargaining. According to the pooled-income hypothesis, divorce reform will only impact female labor supply through its effect on the probability of divorce. In contrast, cooperative bargaining models predict that a shift in the distribution of resources within marriage will influence household decision making.

Gray further argued that the shift in bargaining power when unilateral divorce laws were adopted was determined by the underlying property division laws: bargaining power shifted toward men when property laws favored them and shifted toward women when they were favored by the property laws. As such he argued that "unilateral divorce has no significant impact on married women's labor-force participation unless the underlying marital-property laws in each state are considered" (p. 629). These theoretical predictions and Gray's finding that female employment fell when unilateral divorce is combined with property division laws that

\footnotetext{
${ }^{1}$ See Peters (1986), Parkman(1989), and Peters (1992).
} 
favor men and increases when combined with property division laws that favor women, yielded clear support for cooperative bargaining models.

Unfortunately, the underlying assumption—-that unilateral divorce had no impact on divorce probabilities—-has been subsequently shown to be false. Recent research has revealed that the divorce rate did indeed rise following the adoption of unilateral divorce laws. ${ }^{2}$ While the shift to unilateral divorce only explains a small rise in the probability of divorce, it also leads to a decrease in marital duration as those who do divorce do so more rapidly under unilateral divorce (Matouschek and Rasul, 2006). These two effects reduce the value of specialization within marriage and therefore provide an incentive for married women to increase their labor supply regardless of the underlying laws regarding property division.

Furthermore, while unilateral divorce's affect on the divorce rate appears to dissipate over time, this may partly reflect the impact of unilateral divorce laws on new marriagesmarriage rates fall, with those who do marry following unilateral divorce appearing to be better selected than those who marry under mutual consent laws (Rasul, 2006). These empirical findings imply that women in unilateral divorce states spend less of their adult life in marriage, thus reaping fewer returns from specializing in the home, and having greater incentives to make larger investments in market work. As such, this implication suggests that the labor force participation of all women (who anticipate marriage at some point), not simply married women, should rise, following the passage of unilateral divorce.

While unilateral divorce's impact on time spent in marriage provides an incentive for women to participate in market work regardless of the underlying laws regarding property

\footnotetext{
${ }^{2}$ Friedberg (1998) argued in the same issue of the AER that divorce rates did indeed rise once state-specific linear trends were considered. Since then work by Wolfers (AER 2006) has confirmed a small rise in the divorce rate, showing that there was a dynamic response with divorce rates spiking following the adoption of unilateral divorce and slowly falling subsequently. He argues that the rise in divorce rates lasted about 10 years.
} 
division, its impact on household bargaining may lead to either an increase or a decrease in female employment for those in existing marriages when divorce reform passes. Unilateral divorce shifts bargaining power toward the spouse who values exiting the marriage most. While Gray (1998) assumed that the laws regarding property division determined which spouse values exiting the marriage most, this ignores a host of other factors that affect the value of exiting the marriage, including the strategic behavior of spouses regarding investment in marriage-specific capital. This paper reconsiders how bargaining power is shifted when unilateral divorce is adopted, challenging the assumption that property division laws govern which spouse gains bargaining power when unilateral divorce is adopted.

This paper revisits the question of the effect of divorce reform on female labor supply examining both married and unmarried women's labor force participation. My results suggest that rather than providing support for cooperative bargaining models, the empirical results presented in Gray (1998) reflect omitted variable bias. Correcting for these omitted variables results in estimates of female employment effects that are similar for the adoption of unilateral divorce across all types of property division laws and are close to those estimated in Peters (1986). Furthermore, aggregate data over a longer time period indicate that both married and unmarried women's labor force participation did indeed rise more strongly in unilateral divorce states than in comparison states.

The rest of the paper proceeds as follows: the next section considers how divorce reform may impact married women's labor supply decisions. Section II turns to results, first replicating Gray's results. I then examine an alternative test of Gray's theory: whether unilateral divorce affects female employment differentially for those with property to divide versus those without. I next add state-level aggregate controls and demonstrate that the effect of unilateral divorce is 
invariant to the laws regarding property division once state-level controls have been added. This section further considers the impact by marital duration showing that the impact of unilateral divorce on female employment is greatest for those in the first 15 years of marriage. Finally, I show, using state-level aggregate data, an increase over time in female employment in states that adopt unilateral divorce compared with those that do not. Section IV concludes.

\section{II: Divorce Reform and Married Women's Labor Supply}

Divorce reform may affect female labor supply either because it changes the value of women's bargaining position in the relationship or because it alters the returns to specialization within marriage and thus the returns to market versus non-market work. Additionally, Peters (1986) found a rise in female labor force participation in unilateral divorce states of around 2 percentage points, arguing that unilateral divorce provided an incentive for women to self-insure against divorce by investing in market skills. ${ }^{3}$

Gray (1998) interpreted his empirical estimates as suggesting that women in states where the legal guidelines lead them to receive smaller settlements at divorce have less bargaining power under unilateral divorce than they did under mutual consent divorce. In other words women in these states prefer remaining married more than their husbands do and as such their husbands gain when bargaining power is shifted to the person who values exiting the marriage the most. Gray (1998) argued that because employment in the labor market is less of a joint investment than work in the home, these women who lose bargaining power become less likely to be employed in the labor market. Similarly, women in states that favor ex-wives in property settlements value exiting the marriage more than do their husbands, and thus gain bargaining power with unilateral divorce, and therefore work inside the home less, and thus outside the

\footnotetext{
${ }^{3}$ Peter's findings rely on empirical estimation of a cross-section of states.
} 
home more. In contrast, Chiappori, Fortin, and LaCroix (2002) estimate a structural model where divorce laws enter by shifting the bargaining positions of the spouses. They find that divorce laws that are favorable to women reduce married women's labor supply

The assumption that women gain bargaining power when states with community or equitable property division laws adopt unilateral divorce, and lose bargaining power when common law property division states adopt unilateral divorce, relies on the assumption that on average women in the former states value divorce more, and marriage less, than do men (with the opposite being true in the latter). The Coase theorem is often invoked to understand how a shift from unilateral divorce to mutual consent divorce shifts bargaining powering within the family. Under mutual consent divorce laws the person desiring a divorce must compensate their spouse such that he is at least as well off divorced as married. Such compensation occurs as long as the joint return to divorce exceeds the joint return to remaining married. In contrast, unilateral divorce requires that the person desiring to remain married must compensate their spouse until he is at least as well off married as he would be divorced and again marriages continue when the joint return is maximized by remaining married.

Divorce laws change the value of exiting the marriage. This changes bargaining within households if the relevant threat point is the exit threat. Exit threat bargaining models emphasize each spouse's best option outside the marriage as the relevant parameters determining the intrahousehold distribution. Under mutual consent divorce, the relevant exit threat is to physically, although not legally, leave the marriage. This exit provides no opportunity to remarry or any legal claim to a share of the couple's joint assets. In contrast, unilateral divorce laws provide for a more attractive outside option, thus potentially changing the resulting bargain inside the 
marriage, with bargaining power being redistributed toward those for whom unilateral divorce provides a credible threat to exit the marriage.

Laws regarding the division of property affect the legal parameters for the division of assets, but since spouses know these laws at the time they marry and make subsequent investment decisions, these laws do not uniquely determine which spouse has a higher value of exiting the relationship. For example, if the woman prefers to divorce then the passage of unilateral divorce laws transfers bargaining power to her regardless of the underlying property laws. While she gets more resources when property laws favor women, bargaining power is transferred to the woman even when property laws favor men, as the alternative without unilateral divorce is to leave with no assets at all (or ability to remarry).

So how do we know whether women or men prefer to exit the marriage, and moreover whether this varies by the laws regarding the division of property? First, it is important to note that not all bargaining within marriage is determined by the threat to exit. For many couples who are far from the divorce margin, the relevant threat points are internal to the marriage and thus not impacted by divorce law. ${ }^{4}$ Thus, the empirical question is whether the transfer of bargaining power subsequent to the adoption of unilateral divorce laws varies by gender and by property division laws for those couples for whom the exit threat is relevant.

Empirical work has found that women are more likely to file for divorce: around twothirds of those filing for divorce are women. Brinig and Allen (2000) argue that one reason for this is because women have a greater likelihood of getting custody of their children. Men who value living with their children may therefore value exiting the marriage less than their wife.

\footnotetext{
${ }^{4}$ For information on bargaining models that rely on threat points that are internal to the marriage see Lundberg \& Pollak (1993).
} 
Since property distribution laws don't apply to custody, concerns over custody may impact the value of exiting the marriage in a way that is uncorrelated with property division laws.

Women and men choose whether to marry, whom to marry, and subsequently make decisions within marriage that reflect the underlying property laws. A woman who knows that her spouse will get a greater division of the assets at divorce may choose to invest in fewer shared assets, opting instead to invest in her options outside of marriage. Thus, at the time that unilateral divorce laws pass, theory can provide us with little certainty as to whether men or women are better off under unilateral divorce laws despite knowing the property division laws.

Theory provides much clearer guidance on how unilateral divorce may affect female labor force participation through changing the value of household specialization. Becker's treatise on the family stressed that much of the value of marriage lay in the ability to specialize within marriage; as such, the full benefits from marriage are realized when one spouse specializes in the home, while the other specializes in the market (1981). These specialized skills are highly complementary within a marriage, yet are less useful if single. Thus, if unilateral divorce changes the proportion of one's life spent outside of marriage, either by increasing the probability of divorce, decreasing the expected duration of marriage, or decreasing the probability of marriage, then it decreases the returns to such specialization. Indeed much research has shown that divorce rates rise, marital duration falls, and marriage rates fall in the wake of unilateral divorce. ${ }^{5}$ These empirical findings suggest that women's labor force participation, both while married and prior to marriage, should rise with the adoption of unilateral divorce regardless of the underlying property division laws.

\footnotetext{
${ }^{5}$ Wolfers (2006), Friedberg (1998) both find an increase, albeit small, in divorce resulting from unilateral divorce. Rasul (2006) finds a decrease in the marriage rate and reduced duration of marriage is shown by Matouschek and Rasul (2006).
} 


\section{III: Empirical Results}

Turning to the empirical results, I start by replicating and extending Gray's results using the 1970 and 1980 Censuses of Population. The primary regression he runs

is:

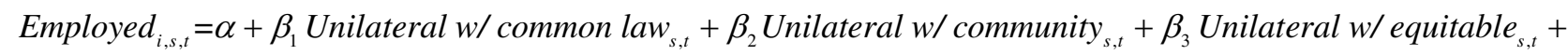

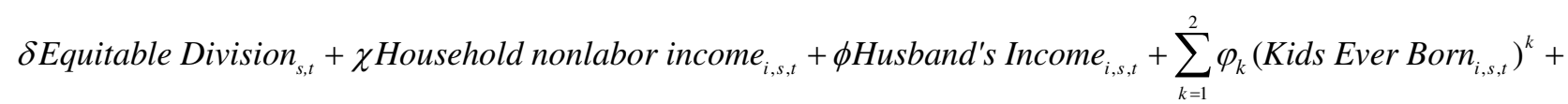
$+\gamma$ Any kids under $\sigma_{i, s, t}+\eta$ Age $_{i, s, t}+\mu$ White $_{i, s, t}+\xi$ Education $_{i, s, t}+\psi$ Urban $_{i, s, t}+\lambda$ Year of Census $_{t}+\sum_{s} \eta_{s}$ State $_{s}+\varepsilon_{i, s, t}$

where the $\beta$ 's are the coefficients of interest. The effect of unilateral divorce is estimated separately for the three property division regimes: common law, community property, and equitable division. ${ }^{6}$ The same specification is also run replacing the three dummy variables with a single indicator variable for unilateral divorce regardless of the type of property division. Gray (1998) reports that one state in his sample changes from common law property division to equitable division over this period; he therefore includes the direct effect of adopting equitable property division in his regressions. ${ }^{7}$ Aside from state and year fixed effects, individual characteristics are included as controls, although many of these controls may themselves be changed by the adoption of unilateral divorce. For instance, existing research has shown an effect of unilateral divorce on fertility. Husband's income is particularly problematic as

6 Gray (1998) codes all states as following into one of these three property division regimes. There is, however, some disagreement among legal scholars over this classification. For instance, this division ignores whether a state had eliminated fault from consider in property division. Additionally, Jacob (1988) goes through property division laws finding that by 198322 states had a provision to value the homemaking contribution of spouses, 19 states had "unequivocally eliminated fault from consideration in property division" (p.121), and 5 states had switched to "equal" distribution, 5 were ambiguous, while the remainder followed equitable division. For consistency, I follow Gray's coding of property division laws and his coding of unilateral divorce laws.

${ }^{7}$ I follow his sample which excludes 5 states that changed their divorce laws in the late 1970s. Only one state in his sample changed from common law property division to equitable division during this period. Thus equitable division is included as a control, common law is the excluded category, and community property is collinear with the state fixed effects and is therefore not included. Following Gray, the control for equitable division is not included when the three dummy variables for unilateral divorce are replaced by a single indicator variable. 
husbands and wives labor are jointly determined, presumably by household bargaining. Thus any policy change that impacts household bargaining may impact both wives and husbands earnings.

The first column of Table 1 reports Gray's primary specification (his Table 3, columns 2 \& 3). ${ }^{8}$ Panel A reports regressions where there are three dummy variables indicating whether a state has unilateral divorce with equitable division, common law, or community property division laws. Panel B reports regressions where the independent variable of interest is measured as a single dummy variable indicating whether the state has unilateral divorce. The second column replicates this specification using the same 1 in 1000 Censuses samples and follows his coding of both the dependent and independent variables. ${ }^{9}$ The replication is nearly exact with coefficient estimates within rounding error at the third decimal place. $^{10}$

The next several columns investigate the hypothesis put forward by Gray that the estimates of the response of married women's labor supply to the adoption of unilateral divorce is governed by how the state will divide property by considering the property that a couple owns. The argument for why unilateral divorce affects women differently in common law states versus equitable division or community property states is that men typically hold title to property in common law states and thus have greater resources upon divorce. The most important asset that most couples divide at divorce is their home (and this asset is also easily held only in the husband's name). As such, we would expect to see differences between home owners and renters in the impact of unilateral divorce laws that vary by property regime, with the results

\footnotetext{
${ }^{8}$ Gray (1998) reports t-statistics. I calculate the implied standard errors and show standard errors rather than tstatistics.

${ }^{9}$ ICPSR studies: 0018 and 8101.

${ }^{10}$ Robust standard errors are reported in parenthesis, calculated to be consistent with Gray (1998). Standard errors clustered at the state level are reported below in brackets. Somewhat surprisingly, clustering yields smaller standard errors.
} 
shown in columns 1 driven by those who own property. What we see instead is that the negative relationship between married women's employment and the adoption of unilateral divorce in states with common law property division is driven largely by those who don't own a home. The change to unilateral divorce leads to a statistically significant 10 percentage point decrease among renters in married women's employment in states with common law property division. In contrast, among home owners unilateral divorce leads to a non-significant 2 percentage point fall. The coefficient on unilateral divorce with community property is similar across the two groups and the coefficient on unilateral divorce with equitable division is positive for both groups, albeit slightly larger for renters.

Similarly, we can disentangle the effects by race. Column 5 shows a large negative effect - a statistically significant decrease in married women's employment of 18 percentage points when unilateral divorce is adopted in states with common law property division. In comparison, non-black married women's employment falls by 1.2 percentage points and is not statistically significant. For blacks there is also a statistically significant fall in married women's employment when unilateral divorce is adopted by states with equitable division property division laws. Looking at community property states, we see a large -10 percentage point—rise in married black women's employment when unilateral divorce is passed. Among non-blacks there is a small increase in married women's employment in both community property and equitable division states that adopt unilateral divorce.

The results shown in columns 3-6 of Table 1 point to the potential for omitted variable bias to be driving the effects found in Gray (1998). ${ }^{11}$ While many researchers have argued for

\footnotetext{
${ }^{11}$ In tables available from the author on request I investigate two groups whose labor force participation should be unaffected by household bargaining: Never married men and women ages 40 to 65 . This older group of never married individuals are unlikely to marry in the future (although it remains possible that being in this group is affected by unilateral divorce laws). The coefficients for never-married men are similar to those shown for married
} 
the exogeneity of the adoption of unilateral divorce laws as they were adopted around the country largely as a procedure refinement to already existing divorce law, there have not been similar arguments made for the exogeneity of property division laws. Furthermore, in parsing this effect out across the three property division regimes there are fewer state changes to identify the effects. For instances, in community property states, all states except Louisiana had unilateral divorce by 1973. Among common law states, 4 states changed their divorce laws to allow unrestricted unilateral divorce-Alabama, Florida, Georgia, and Rhode Island. The majority of the states, 29, follow equitable division which had 4 states change their divorce law to allow unilateral divorce prior to 1970,17 that changed between 1970 and 1980, and 8 that had not adopted unilateral divorce by 1980 . The few states with community property or commonlaw property division laws may also have had other policy changes during the 1970s. Abortion laws were changing, food stamp programs were being introduced and expanded, AFDC varied and was changing, including AFDC for married couples through the AFDC-Unemployed Parent program.

Table 2 seeks to reconsider Gray's results, eliminating the endogenous individual control variables, adding in control variables for state-level demographics and male unemployment, and finally adding in controls for other policy changes that impacted families and potentially married women's employment. Additionally, I use the 1 in 100 census files provided by IPUMS which both provide a larger sample and ensure uniform coding of variables across the years.

The first column shows that dropping the potentially endogenous variables attenuates the estimated coefficients (the remaining individual level controls include a quadratic for age, a

women. Never-married men are more likely to work when states that have community property laws or equitable division laws adopted unilateral divorce and less likely to work in states that adopted unilateral divorce with common law property division. Never married women are more likely to work when unilateral divorce is adopted regardless of the underlying laws governing property division. These findings point to the importance of investigating omitted variable bias and sample selection effects further. 
saturated set of dummy variables for educational attainment, and race). ${ }^{12}$ Panel A shows a negative relationship between married women's employment and unilateral divorce in common law states and a positive relationship for unilateral divorce in equitable and community property division states and Panel B shows no statistically significant effect of unilateral divorce when the effect is not allowed to vary by property laws. The next column adds controls for time-varying factors at the state-level, such as the natural log of state personal income per capita, age composition variables indicating the share of states' populations aged 26-40, 41-55, 56-65, and over 65 , the share of the state's population that is black, and the male unemployment rate. The estimated effects in Panel A are now all positive, albeit not statistically significant. Panel B shows an effect of unilateral divorce on married women's labor supply of 0.4 percentage points - similar to that estimated by Gray. While Gray concluded that there was no effect on unilateral divorce on married women's labor supply unless the underlying property division laws were considered the estimate here, and that in Gray, is imprecisely measured and would allow effects in either direction.

The third column adds controls for time-varying state-level policy such as the presence of a food stamp program, the presence of welfare for families with an unemployed parent, the maximum AFDC rate for a family of four, and whether a state allows abortion. Both Panels A \& B now show statistically significant increases in married women's labor force participation of about one-percentage point when unilateral divorce is adopted-regardless of the underlying laws governing property division at divorce. Breaking this effect across the three property regimes shows coefficient estimates that are similar across the three types of property laws. The

\footnotetext{
${ }^{12}$ This includes correcting the coding of race. Gray coded Hispanics in only states sharing a border with Mexico as non-white in 1970 and all Hispanics were coded as non-white in 1980. This derives from using two different variables-Spanish surname and Hispanic - to define white. Since Hispanic is available for 1970 and 1980 a consistent coding is available for these two periods. However, it is not possible to code Hispanic in 1960 consistently across all states.
} 
next column includes the states that were dropped from Gray's analysis: Massachusetts, Montana, Rhode Island, Wisconsin, and Missouri (Gray dropped them because they changed their divorce laws in the mid 1970s and therefore have less time to impact behavior). The estimated coefficients remain similar when these states are included, albeit attenuated slightly. The next few columns show that the large differences in effects on renters versus non-renters and blacks versus non-blacks that were evident in Table1 are no longer evident once controls are added for time-varying state-characteristics.

Tables 1 and 2 point to the problem of omitted variable bias in determining whether unilateral divorce impacted married women's labor force participation. Table 3 considers whether selection into and out of marriage is affecting the estimates of the effect of unilateral divorce on married women's labor force participation by examining the impact by marital duration. These columns show that unilateral divorce has the largest impact on the labor force participation of women married 5-10 years, the period during which many marriages are most likely to end. This relationship suggests that the threat of divorce is playing a role in the relationship between unilateral divorce and whether married women work.

The results thus far have not been able to adequately address pre-existing trends. The difficulty of establishing a relationship between unilateral divorce and marital outcomes given the pre-existing differences among states in changes in norms and behavior regarding marriage has led scholars to examine data sets that cover a long period and allow the dynamic response of the policy change to be explicitly mapped out. The difficulty with married women's labor force participation is that the Current Population Statistics groups several states together during the 1970s reducing the number of state-years available for analysis. 
Figures 1a and $1 \mathrm{~b}$ shows the aggregate labor force participation rates of married and all women respectively using annual data from the March CPS. These figures show that female labor force participation rose in the mid-1970s in states that adopted unilateral divorce relative to those that did not (while states vary in the timing of adoption, states are simply grouped into those that adopt unilateral divorce and those that do not). This rise for married women appears to last about 10 years. In contrast, the labor force participation rates for all women rose and remain about 2 percentage points higher in unilateral divorce states. This difference reflects the greater labor force participation rates for unmarried women as well as married women. This result is consistent with results that find lower marriage rates in unilateral divorce states; as a result, unmarried women have a greater incentive to invest in market skills.

Table 4 examines these results exploiting the variation that comes from differences across states in the timing of the adoption of unilateral divorce. Furthermore, the regression format includes leads and lags for unilateral divorce to see if the timing evidence supports a role for unilateral divorce in increasing female labor force participation. The CPS is potentially problematic because several states are grouped together between 1968 and 1972 and others are grouped together between 1973 and 1976. Only around a quarter of the states are separately identified over the entire period. I use all available state-years in the regressions shown in Table 4; however the results are similar when I include only states that can be individually identified each year between 1968 and 1995.

The specification in the first column examines the relationship between unilateral divorce and the employment of all women. By looking at all women, we look at the total effect on employment - that stemming from changes in marital behavior as well as from changes within marriage. The second column adds state-level aggregate controls. Both columns show a clear 
rise in female labor force participation that begins a few years after unilateral divorce is adopted. Adding controls increases the estimated coefficients and sharpens the estimates. Both specifications suggested that within 5 years of unilateral divorce female employment has risen by 2-3 percentage points.

Columns 3-4 in Table 4 show a less consistent pattern for married women. As was seen in the earlier tables, the relationship between unilateral divorce and married women's employment is sensitive to the inclusion of state-level aggregate controls. The first column does not include controls for other time varying state-level factors and we see a small and insignificant effect of unilateral divorce on married women's labor supply. Adding controls leads to statistically significant increase of 2-3 percentage points that is not seen in the years leading up to unilateral divorce and grows following the adoption of unilateral divorce.

\section{IV: Conclusion}

This paper examines how changing the laws governing divorce and property division change women's labor supply decisions. Divorce laws change the value of exiting the marriage and thus potentially change bargaining within the household. These laws also potentially change the returns to specialization in household production by reducing the amount of time women can expect to spend in marriage and by increasing the returns to investing in one's options outside of marriage. In earlier work Gray (1998) argued that there was no direct affect of unilateral divorce on female labor supply; rather the impact of unilateral divorce depends on the prevailing laws governing property division. This paper revisits this question finding that the inability to find an effect of unilateral divorce on female labor supply reflected omitted variable bias and heterogeneity in treatment for women based on marital duration. Moreover, the small number of states following common law property division and adopting unilateral divorce makes the 
finding of a negative effect on female employment in these states very sensitive to the sample and specification used.

This paper adds a richer set of controls for state level time-varying factors and finds that adding these controls yields estimates that imply an effect of unilateral divorce on female employment that is similar across legal regimes for the division of property at divorce. These findings suggest that unilateral divorce led to a 1 percentage point rise in female employment. Considering martial duration leads to estimates that are double for those in the earlier years of marriage, with little effect found for those married for 15 years or longer. Examining 25 years of data shows an increase in female employment for both married and unmarried women following unilateral divorce that reaches its peak 5 years after unilateral divorce is adopted and remains about 2 percentage points higher than that in states that did not adopt unilateral divorce. These findings point to divorce reform's broader impact on the behavior of individuals both within and outside of marriage. 


\section{References}

Brinig, Margaret and Allen, Douglas. (2000). "These Boots Are Made for Walking": Why Most Divorce Filers Are Women. American Law and Economics Review, 2, 126-69.

Chiappori, Pierre-Andre, Bernard Fortin and Guy Lacroix (2002) "Marriage Market, Divorce Legislation and Household Labor Supply”, Journal of Political Economy.

Drewianka, Scott (2006) "Divorce Law and Family Formation”, Journal of Population Economics, forthcoming.

Ellman, Ira M. and Sharon L. Lohr (1998) "Dissolving the Relationship Between Divorce Laws and Divorce Rates", International Review of Law and Economics 18.

Friedberg, Leora (1998) "Did Unilateral Divorce Raise Divorce Rates? Evidence From Panel Data", American Economic Review, 88(3).

Gray, Jeffrey S. (1998) "Divorce-Law Changes, Household Bargaining, and Married Women's Labor Supply", American Economic Review, 88(3)

Jacob, Herbert (1988) Silent Revolution: The Transformation of Divorce Law in the United States. University of Chicago Press:Chicago.

Lundberg, Shelly and Robert A. Pollak, "Noncooperative Bargaining Models of Marriage," American Economic Review, LXXXIV (1994), 132-37. and ___ "Separate Spheres Bargaining and the Marriage Market," Journal of Political Economy, CI (1993), 988-1010.

Matouschek and Rasul (2006) "The economics of the marriage contract: theories and evidence, Journal of Law and Economics, forthcoming

Parkman, Allen (1992) "Unilateral Divorce and the Labor-Force Participation rate of Married Women, Revisited" American Economic Review, 82(3).

Peters, H. Elizabeth (1986) "Marriage and Divorce: Informational Constraints and Private Contracting", American Economic Review, 76 (3): 437-54.

1992. Marriage and divorce: Reply. American Economic Review 82, no. 3:687-93.

Rasul, Imran (2006) “The Impact of Divorce Laws on Marriage”, mimeo, University College, London.

Stevenson, Betsey and Justin Wolfers (2006) "Bargaining in the Shadow of the Law: Divorce Laws and Family Distress", Quarterly Journal of Economics, 121(1). 
Stevenson, Betsey (2007) "The Impact of Divorce Laws on Investment in Marriage Specific Capital” Journal of Labor Economics, 25 (1): 75-94.

Weitzman, Lenore (1985) The Divorce Revolution New York: Free Press.

Wolfers, Justin (2006) "Did Unilateral Divorce Raise Divorce Rates? A Reconciliation and New Results", American Economic Review, forthcoming. 


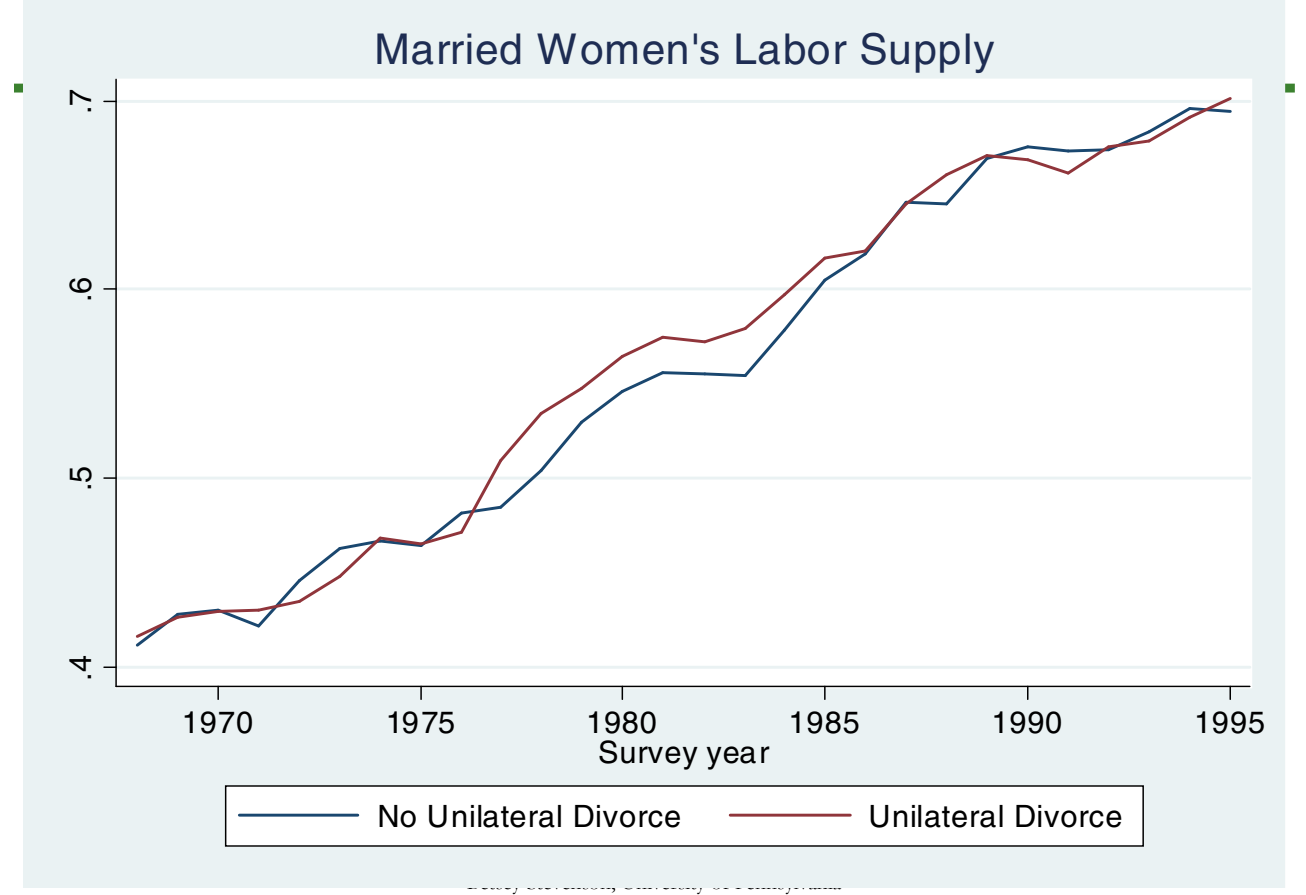

Total Women's Labor Supply

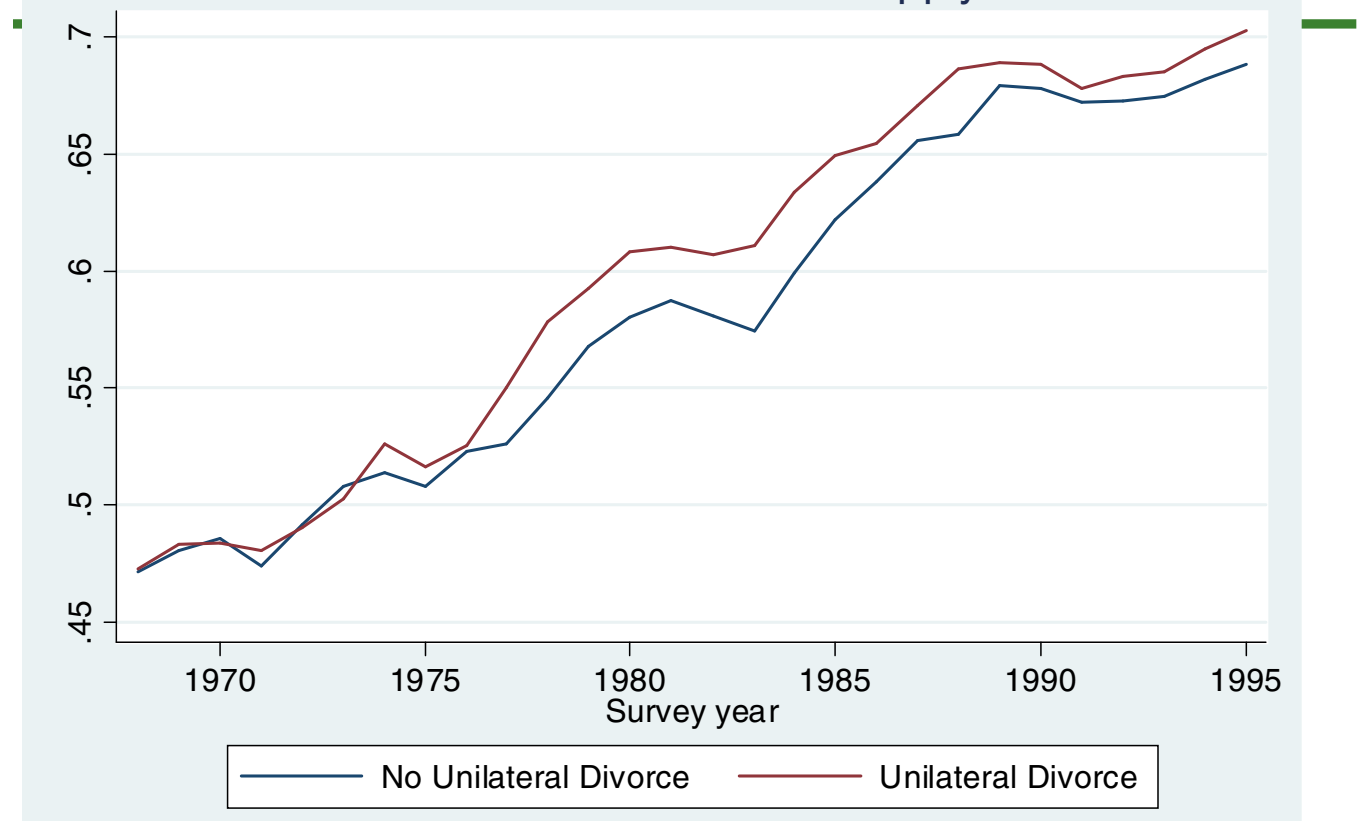


Table 1: Female Employment and the Adoption of Unilateral Divorce with Different Property Division Laws: Comparing Effects for Different Groups

\begin{tabular}{|c|c|c|c|c|c|c|}
\hline & $\begin{array}{c}\text { Gray } \\
\text { (AER } \\
1998)\end{array}$ & Replication & Renters & $\begin{array}{l}\text { Home } \\
\text { Owners }\end{array}$ & Black & Non-black \\
\hline & $(1)$ & $(2)$ & (3) & $(4)$ & $(5)$ & (6) \\
\hline \multicolumn{7}{|l|}{ Panel A } \\
\hline $\begin{array}{r}\text { Unilateral divorce w/ } \\
\text { common law }\end{array}$ & $\begin{array}{l}-.036 \\
(.015)\end{array}$ & $\begin{array}{l}-.037 \\
(.016) \\
\{.004\} \\
\end{array}$ & $\begin{array}{l}-.100 \\
(.032) \\
\{.012\}\end{array}$ & $\begin{array}{l}-.017 \\
(.018) \\
\{.005\}\end{array}$ & $\begin{array}{l}-.178 \\
(.046) \\
\{.022\}\end{array}$ & $\begin{array}{l}-.012 \\
(.017) \\
\{.004\}\end{array}$ \\
\hline $\begin{array}{l}\text { Unilateral divorce w/ } \\
\text { equitable distribution }\end{array}$ & $\begin{array}{c}.013 \\
(.010)\end{array}$ & $\begin{array}{c}.013 \\
(.011) \\
\{.008\} \\
\end{array}$ & $\begin{array}{c}.023 \\
(.021) \\
\{.013\} \\
\end{array}$ & $\begin{array}{c}.009 \\
(.012) \\
\{.009\} \\
\end{array}$ & $\begin{array}{l}.026 \\
(.048) \\
\{.018\} \\
\end{array}$ & $\begin{array}{c}.011 \\
(.011) \\
\{.008\} \\
\end{array}$ \\
\hline $\begin{array}{l}\text { Unilateral divorce w/ } \\
\text { community property }\end{array}$ & $\begin{array}{l}.023 \\
(.012)\end{array}$ & $\begin{array}{c}.024 \\
(.012) \\
\{.005\}\end{array}$ & $\begin{array}{c}.023 \\
(.021) \\
\{.011\}\end{array}$ & $\begin{array}{c}.028 \\
(.014) \\
\{.008\}\end{array}$ & $\begin{array}{c}.113 \\
(.043) \\
\{.020\}\end{array}$ & $\begin{array}{c}.022 \\
(.012) \\
\{.005\}\end{array}$ \\
\hline \multicolumn{7}{|l|}{ Panel B } \\
\hline Unilateral & $\begin{array}{c}.006 \\
(.008)\end{array}$ & $\begin{array}{c}.006 \\
(.008) \\
\{.007\} \\
\end{array}$ & $\begin{array}{l}.000 \\
(.016) \\
\{.013\} \\
\end{array}$ & $\begin{array}{c}.008 \\
(.010) \\
\{.008\} \\
\end{array}$ & $\begin{array}{l}.053 \\
(.031) \\
\{.036\} \\
\end{array}$ & $\begin{array}{r}.010 \\
(.009) \\
\{.006\} \\
\end{array}$ \\
\hline Sample size & 63,615 & 63,615 & 16,842 & 46,622 & 4,977 & 58,631 \\
\hline
\end{tabular}

Notes: All columns report Probit estimates, evaluated at the cell mean.

Robust standard errors are in parentheses. Standard errors clustered at the level of the state-year are in curly brackets.

Regression specification follows Gray (1998). Controls include state and year fixed effects, a dummy for non-hispanic white (Hispanics were not identified in most states prior to 1980), a dummy for urban status, non-labor household income, husbands income, number of kids ever born , kids ever born squared, any kids under 6 , years of education, age. 
Table 2: Female Employment and the Adoption of Unilateral Divorce with Different Property Division Laws: Adding State-Level Controls

\begin{tabular}{|c|c|c|c|c|c|c|c|c|}
\hline & $\begin{array}{c}\text { Minimal } \\
\text { controls } \\
(1 \% \text { Sample })\end{array}$ & $\begin{array}{c}\text { +Aggregate } \\
\text { state-level } \\
\text { demographic } \\
\text { controls }\end{array}$ & $\begin{array}{c}\text { +Aggregate } \\
\text { state-level } \\
\text { policy } \\
\text { controls }\end{array}$ & $\begin{array}{l}\text { +Excluded } \\
\text { states }\end{array}$ & Renters & $\begin{array}{l}\text { Home } \\
\text { Owners }\end{array}$ & Black & Non-Black \\
\hline & (1) & (2) & (3) & (4) & $(5)$ & (6) & (7) & $(8)$ \\
\hline \multicolumn{9}{|l|}{ Panel A } \\
\hline $\begin{array}{r}\text { Unilateral divorce w/ } \\
\text { common law }\end{array}$ & $\begin{array}{l}-.010 \\
(.005) \\
\{.003\} \\
\end{array}$ & $\begin{array}{l}.008 \\
(.007) \\
\{.008\} \\
\end{array}$ & $\begin{array}{c}.010 \\
(.007) \\
\{.009\} \\
\end{array}$ & $\begin{array}{l}.009 \\
(.007) \\
\{.008\} \\
\end{array}$ & $\begin{array}{l}-.003 \\
(.013) \\
\{.015\}\end{array}$ & $\begin{array}{c}.011 \\
(.008) \\
\{.007\}\end{array}$ & $\begin{array}{c}.011 \\
(.021) \\
\{.077\}\end{array}$ & $\begin{array}{c}.011 \\
(.007) \\
\{.010\} \\
\end{array}$ \\
\hline $\begin{array}{l}\text { Unilateral divorce } \mathrm{w} / \\
\text { equitable distribution }\end{array}$ & $\begin{array}{r}.005 \\
(.003) \\
\{.006\} \\
\end{array}$ & $\begin{array}{c}.005 \\
(.004) \\
\{.005\} \\
\end{array}$ & $\begin{array}{r}.012 \\
(.005) \\
\{.007\} \\
\end{array}$ & $\begin{array}{r}.013 \\
(.005) \\
\{.005\} \\
\end{array}$ & $\begin{array}{c}.005 \\
(.010) \\
\{.008\} \\
\end{array}$ & $\begin{array}{c}.017 \\
(.005) \\
\{.006\} \\
\end{array}$ & $\begin{array}{l}-.017 \\
(.024) \\
\{.016\}\end{array}$ & $\begin{array}{c}.013 \\
(.005) \\
\{.005\} \\
\end{array}$ \\
\hline $\begin{array}{l}\text { Unilateral divorce } \mathrm{w} / \\
\text { community property }\end{array}$ & $\begin{array}{c}.004 \\
(.004) \\
\{.003\} \\
\end{array}$ & $\begin{array}{c}.001 \\
(.006) \\
\{.006\} \\
\end{array}$ & $\begin{array}{r}.010 \\
(.008) \\
\{.009\} \\
\end{array}$ & $\begin{array}{c}.009 \\
(.008) \\
\{.009\} \\
\end{array}$ & $\begin{array}{c}.009 \\
(.015) \\
\{.015\}\end{array}$ & $\begin{array}{c}.006 \\
(.010) \\
\{.009\}\end{array}$ & $\begin{array}{l}-.030 \\
(.043) \\
\{.025\}\end{array}$ & $\begin{array}{c}.011 \\
(.008) \\
\{.010\} \\
\end{array}$ \\
\hline \multicolumn{9}{|l|}{ Panel B } \\
\hline Unilateral & $\begin{array}{c}.001 \\
(.003) \\
\{.003\} \\
\end{array}$ & $\begin{array}{c}.004 \\
(.003) \\
\{.004\} \\
\end{array}$ & $\begin{array}{c}.011 \\
(.004) \\
\{.006\} \\
\end{array}$ & $\begin{array}{c}.012 \\
(.004) \\
\{.005\} \\
\end{array}$ & $\begin{array}{c}.003 \\
(.008) \\
\{.008\} \\
\end{array}$ & $\begin{array}{c}.014 \\
(.004) \\
\{.005\} \\
\end{array}$ & $\begin{array}{l}-.006 \\
(.017) \\
\{.010\} \\
\end{array}$ & $\begin{array}{r}.012 \\
(.004) \\
\{.005\} \\
\end{array}$ \\
\hline Reduced set of controls & $\checkmark$ & $\checkmark$ & $\checkmark$ & $\checkmark$ & $\checkmark$ & $\checkmark$ & $\checkmark$ & $\checkmark$ \\
\hline $\begin{array}{l}\text { State-level demographic } \\
\text { controls }\end{array}$ & & $\checkmark$ & $\checkmark$ & $\checkmark$ & $\checkmark$ & $\checkmark$ & $\checkmark$ & $\checkmark$ \\
\hline State-level policy controls & & & $\checkmark$ & $\checkmark$ & $\checkmark$ & $\checkmark$ & $\checkmark$ & $\checkmark$ \\
\hline Sample size & 656,375 & 656,375 & 656,375 & 695,488 & 185,876 & 509,612 & 51,755 & 643,725 \\
\hline
\end{tabular}

Notes: All columns report Probit estimates, evaluated at the cell mean.

Robust standard errors are in parentheses. Standard errors clustered at the level of the state-year are in curly brackets.

The reduced set of controls includes dummy variables for white and black, a quadratic for age, a saturated set of dummy variables for education, along with state and year fixed effects.

State-level demographic controls include age composition variables indicating the share of states' populations aged 26-40, 41-55, 56-65, and over 65, the share of the state's population that is black, white and other the natural log of state personal income per capita, the unemployment rate.

State-level policy controls include the maximum AFDC rate for a family of four, existence of the AFDC unemployed parent and food stamp programs, and the Donahue and Levitt coding of whether a state has abortion access 
Table 3: Female Employment and the Adoption of Unilateral Divorce with Different Property Division Laws: Heterogeneity and Selection

\begin{tabular}{|c|c|c|c|c|}
\hline & $\begin{array}{l}\text { Married } 5 \\
\text { years or } \\
\text { less }\end{array}$ & $\begin{array}{l}\text { Married 5- } \\
10 \text { years }\end{array}$ & $\begin{array}{l}\text { Married } \\
11-15 \\
\text { years }\end{array}$ & $\begin{array}{l}\text { Married } \\
\text { more than } \\
15 \text { years }\end{array}$ \\
\hline & $(1)$ & (2) & (3) & (4) \\
\hline \multicolumn{5}{|l|}{ Panel A } \\
\hline $\begin{array}{r}\text { Unilateral divorce } \\
\text { w/ equitable } \\
\text { distribution }\end{array}$ & $\begin{array}{l}.017 \\
(.010) \\
\{.007\}\end{array}$ & $\begin{array}{l}.014 \\
(.013) \\
\{.008\}\end{array}$ & $\begin{array}{l}.013 \\
(.013) \\
\{.010\}\end{array}$ & $\begin{array}{l}.016 \\
(.007) \\
\{.008\}\end{array}$ \\
\hline $\begin{array}{l}\text { Unilateral divorce } \\
\text { w/ common law }\end{array}$ & $\begin{array}{l}-.008 \\
(.015) \\
\{.012\}\end{array}$ & $\begin{array}{l}.049 \\
(.018) \\
\{.014\}\end{array}$ & $\begin{array}{l}.034 \\
(.019) \\
\{.014\}\end{array}$ & $\begin{array}{l}-.007 \\
(.010) \\
\{.010\}\end{array}$ \\
\hline $\begin{array}{r}\text { Unilateral divorce } \\
\mathrm{w} / \text { community } \\
\text { property }\end{array}$ & $\begin{array}{l}-.020 \\
(.018) \\
\{.012\} \\
\end{array}$ & $\begin{array}{l}.019 \\
(.022) \\
\{.014\} \\
\end{array}$ & $\begin{array}{l}.018 \\
(.023) \\
\{.013\} \\
\end{array}$ & $\begin{array}{r}.015 \\
(.013) \\
\{.011\} \\
\end{array}$ \\
\hline \multicolumn{5}{|l|}{ Panel B } \\
\hline Unilateral & $\begin{array}{c}.006 \\
(.008) \\
\{.007\} \\
\end{array}$ & $\begin{array}{l}.025 \\
(.010) \\
\{.007\} \\
\end{array}$ & $\begin{array}{r}.020 \\
(.011) \\
\{.008\} \\
\end{array}$ & $\begin{array}{c}.004 \\
(.006) \\
\{.007\} \\
\end{array}$ \\
\hline $\begin{array}{l}\text { State-level aggregate } \\
\text { controls and reduced } \\
\text { individual level }\end{array}$ & $\sqrt{ }$ & $\sqrt{ }$ & $\sqrt{ }$ & $\sqrt{ }$ \\
\hline Sample size & 125,050 & 100,499 & 89,211 & 283,765 \\
\hline
\end{tabular}

Notes: All columns report Probit estimates, evaluated at the cell mean.

Robust standard errors are in parentheses. Standard errors clustered at the level of the state-year are in curly brackets.

The reduced set of controls includes dummy variables for white and black, a quadratic for age, a saturated set of dummy variables for education, along with state and year fixed effects.

State-level aggregate controls include the maximum AFDC rate for a family of four, existence of the AFDC unemployed parent and food stamp programs, the natural log of state personal income per capita, the unemployment rate, age composition variables indicating the share of states' populations aged 26-40, 41-55, 56-65, and over 65, the Donahue and Levitt coding of whether a state has abortion access, and the share of the state's population that is black, white and other. 
TABLE 4

\section{Effects of Unilateral Divorce on Female Employment}

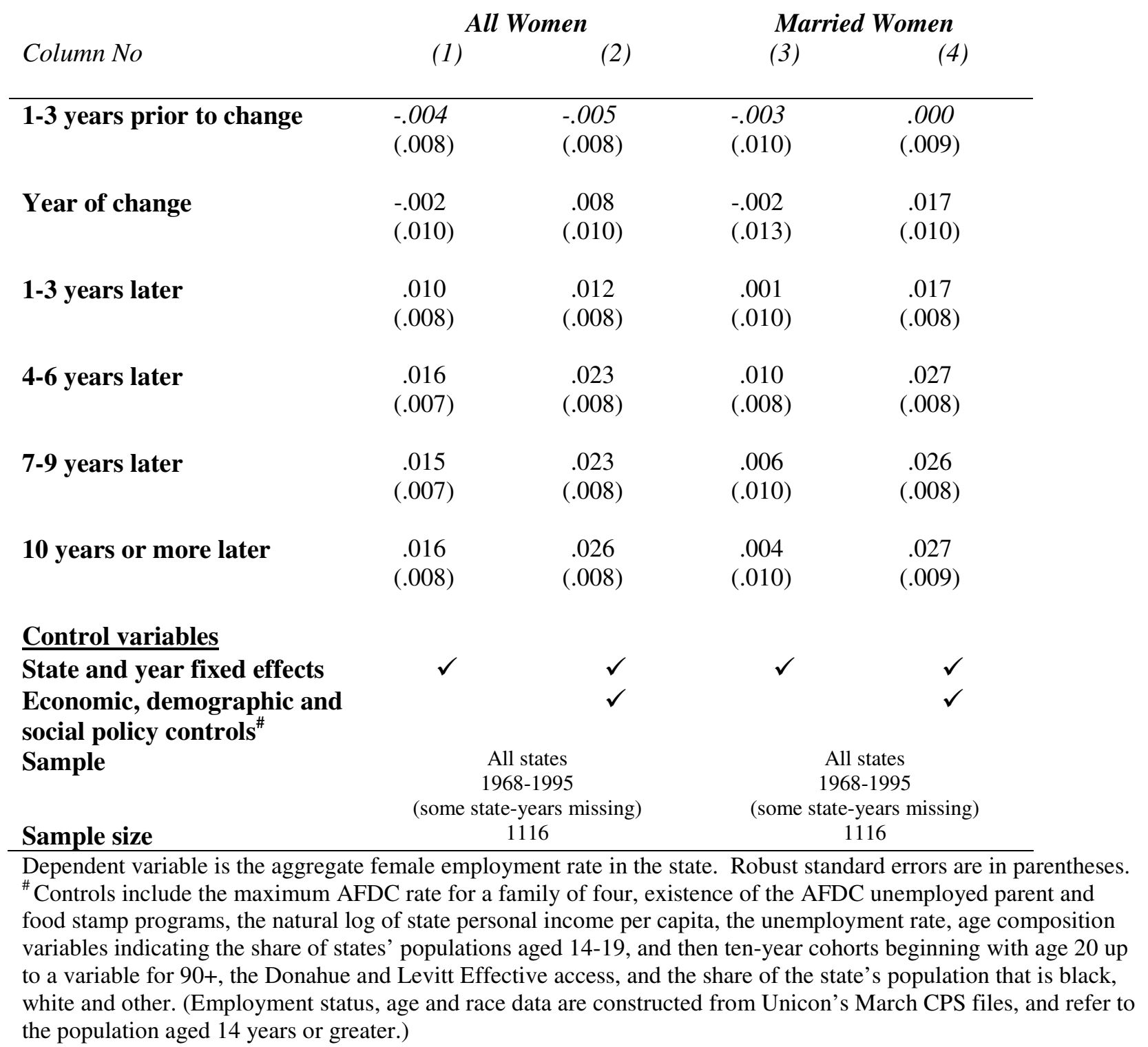

